\title{
Vitamin D deficiency and tuberculosis: what about body mass index?
}

This article was published in the following Dove Press journal:

Drug Design, Development and Therapy

II April 2017

Number of times this article has been viewed

\section{Eduardo Hernández- Garduño}

Research Unit, State Oncology Centre, Social Security Institute of the State of Mexico and Municipalities (ISSEMyM), Toluca, State of Mexico, Mexico
Correspondence: Eduardo HernándezGarduño

Unidad de Investigación Básica Aplicada (UIBA) Centro Oncológico Estatal (COE), Instituto de Seguridad Social del Estado de México y Municipios (ISSEMYM), Avenida Solidaridad las Torres \#I0I, Colonia del Parque, Toluca, Estado de México, CP 50180, México Tel +52 I 7222766820 ext 2934 Email epidemiologist.researcher@ gmail.com

\section{Dear editor}

Huang et al conducted a meta-analysis of published studies on various aspects of association between vitamin D and tuberculosis (TB). ${ }^{1}$ The study concluded that vitamin D deficiency (VDD) was associated with higher risk of TB. However, low body mass index (BMI), a well-recognized and a stronger risk factor of TB than VDD, was not mentioned in this review nor was it accounted for in the multivariable analysis in the majority of case-control studies included in the meta-analysis exploring the association between TB and VDD. Vitamin D levels are likely to be positively correlated with weight/BMI. Infected people who are underweight by $\geq 15 \%, 10 \%-14 \%$ and $5 \%-9 \%$ are at increased risk of progression to TB disease with 2.6, 2.0 and 2.2 cases per 1,000 person-year, respectively. ${ }^{2}$ Contradictory results were found in the few studies of this meta-analysis ${ }^{1}$ that considered weight/BMI in the multivariable analysis. One study showed a weak association between VDD and TB (odds ratio: $1.07,95 \%$ confidence interval 1.01-8.52) but only in men. ${ }^{3}$ Another study found no such association. ${ }^{4}$

Protein-calorie malnutrition is recognized as a well-established risk factor of TB disease, if not the strongest. ${ }^{5}$ Some studies in the meta-analysis ${ }^{1}$ consistently showed that TB patients have lower weight/BMI as compared to controls and therefore this should always be considered in the multivariable analysis assessing nutritional risk factors of TB. Besides low levels of vitamin D, underweight TB patients likely have low levels of other vitamins, calcium, albumin, ferritin or cholesterol (to mention a few) as shown by some studies included in Huang et al meta-analysis. ${ }^{1}$

Future studies focusing on nutritional deficiency risk factors for TB should consider all of these factors together and/or independently as playing a role.

\section{Disclosure}

The author reports no conflicts of interest in this communication.

\section{References}

1. Huang SJ, Wang XH, Liu ZD, et al. Vitamin D deficiency and the risk of tuberculosis: a meta-analysis. Drug Des Devel Ther. 2017;11:91-102.

2. Targeted tuberculin testing and treatment of latent tuberculosis infection. This official statement of the American Thoracic Society was adopted by the ATS Board of Directors, July 1999. This is a Joint Statement of the American Thoracic Society (ATS) and the Centers for Disease Control and Prevention (CDC). This statement was endorsed by the Council of the Infectious Diseases Society of America. (IDSA), September 1999, and the sections of this statement. Am J Respir Crit Care Med. 2000; 161(4 Pt 2):S221-S247.

3. Ho-Pham LT, Nguyen ND, Nguyen TT, et al. Association between vitamin D insufficiency and tuberculosis in a Vietnamese population. BMC Infect Dis. 2010;10:306. 
4. Wejse C, Olesen R, Rabna P, et al. Serum 25-hydroxyvitamin D in a West African population of tuberculosis patients and unmatched healthy controls. Am J Clin Nutr. 2007;86(5):1376-1383.
5. Koethe JR, von Reyn CF. Protein-calorie malnutrition, macronutrient supplements, and tuberculosis. Int J Tuberc Lung Dis. 2016;20(7): $857-863$

Dove Medical Press encourages responsible, free and frank academic debate. The content of the Drug Design, Development and Therapy 'letters to the editor' section does not necessarily represent the views of Dove Medical Press, its officers, agents, employees, related entities or the Drug Design, Development and Therapy editors. While all reasonable steps have been taken to confirm the content of each letter, Dove Medical Press accepts no liability in respect of the content of any letter, nor is it responsible for the content and accuracy of any letter to the editor.

\section{Publish your work in this journal}

Drug Design, Development and Therapy is an international, peerreviewed open-access journal that spans the spectrum of drug design and development through to clinical applications. Clinical outcomes, patient safety, and programs for the development and effective, safe, and sustained use of medicines are the features of the journal, which has also been accepted for indexing on PubMed Central. The manuscript management system is completely online and includes a very quick and fair peer-review system, which is all easy to use. Visit http://www.dovepress.com/testimonials.php to read real quotes from published authors.

Submit your manuscript here: http://www.dovepress.com/drug-design-development-and-therapy-journal 